\title{
EFEKTIFITAS PEMBERIAN KAPUR PERTANIAN DAN KOMPOSISI BERBAGAI MEDIA TANAM BAHAN ORGANIK PADAT PADA PERTUMBUHAN BIBIT KELAPA SAWIT (Elaeis guineensis Jacq) DI PEMBIBITAN AWAL
}

\author{
Elkawaril Ramadhanul Panjaitan \\ Program Studi Budidaya Perkebunan, Fakultas Pertanian dan Peternakan, Universitas Tjut Nyak Dhien, \\ Medan 20123, Sumatera Utara, Indonesia. \\ Tengku Boumedine Hamid Zulkifli* \\ Program Studi Agroteknologi, Fakultas Pertanian dan Peternakan, Universitas Tjut Nyak Dhien, Medan \\ 20123, Sumatera Utara, Indonesia. Email: tengku_bobhz@yahoo.co.id \\ Irwan Agusnu Putra \\ Program Studi Agroteknologi, Fakultas Pertanian dan Peternakan, Universitas Tjut Nyak Dhien, Medan \\ 20123, Sumatera Utara, Indonesia.
}

\begin{abstract}
Abstrak
Penelitian ini bertujuan untuk mengkaji efektifitas pemberian kapur pertanian (KapTan) dan komposisi berbagai media tanam bahan organik padat pada pertumbuhan bibit kelapa sawit (Elaeis guineensis Jacq) di pembibitan awal. Penelitian dilakukan dengan menggunakan Rancangan Acak Kelompok (RAK) faktorial dengan dua faktor. faktor pertama yaitu pemberian pupuk kalsium dengan 3 taraf: $\mathrm{P}_{0}=$ tanpa pupuk kalsium, $\mathrm{P}_{1}=$ pupuk kalsium 2 ton/ha $(10 \mathrm{~g} /$ polybag $), \mathrm{P}_{2}=$ pupuk kalsium 4 ton/ha $(20 \mathrm{~g} / \mathrm{polybag})$. Faktor kedua yaitu media tanam dengan 4 taraf: $M_{0}=$ topsoil, $M_{1}=$ topsoil + kompos kandang sapi (1:1) $M_{2}=$ topsoil + sludge padat (1:1) dan $M_{3}=$ topsoil + kompos TKKS (1:1). Hasil Penelitian ini menunjukkan bahwa interaksi pupuk kalsium dan ragam media tanam terhadap pertumbuhan vegetative bibit tanaman kelapa sawit belum dapat memberikan pengaruh yang nyata pada tinggi tanaman, luas daun, volume akar, bobot basah tanaman, bobot kering tanaman, bobot basah akar tanaman, bobot kering akar tanaman kelapa sawit di pembibitan awal. Media tanam yang terbaik adalah Media tanam top soil dengan kompos kandang sapi dan Media tanam topsoil dengan kompos TKKS serta perlakuan yang terbaik pada perlakuan $\mathrm{M}_{1} \mathrm{P}_{1}$.
\end{abstract}

Kata Kunci: bibit kelapa sawit, kapur pertanian, media tanam

\section{PENDAHULUAN}

Melihat pentingnya tanaman kelapa sawit dewasa ini dan masa yang akan dating serta meningkatnya kebutuhan penduduk akan minyak sawit peranan agronomi sangat berperan adalah masalah pembibitan. Media pembibitan kelapa sawit pada umumnya terdiri atas tanah lapisan atas (topsoil) yang dicampur dengan pasir maupun bahan organic sehingga diperoleh media dengan kesuburan yang baik (Suherman et al., 2007).

Tanaman kelapa sawit memerlukan media tanah yang bersifat permeabel (mudah meloloskan dan menyerap air dan udara tanah), dan lapisan tanah yang tebal, serta kandungan air pada tanah, yang sesuai kebutuhan tanaman (Riwandi, 2004).

Pertumbuhan dan perkembangan tanaman tidak terlepas dari ketersediaan hara berupa pemupukan, baik itu pupuk organik ataupun pupuk anorganik. Pemberian pupuk dipembibitan merupakan salah satu langkah agar pertumbuhan dan perkembangan tanaman yang pada akhirnya dapat meningkatkan produksi tanaman (Sutanto et al., 2002).

Pemberian pupuk kalsium ternyata sangat diperlukan untuk pertumbuhan meristem dan menjamin pertumbuhan dan berfungsinya ujung-ujung akar (Sarief, 1993). Hal ini juga diperkuat pada penelitian Azis \& Langi, (2010) menyatakan bahwa pemberian kapur (Ca) sebanyak 10 ton/ha dan pupuk kandang sapi 10 ton/ha memberikan hasil terbaik terhadap pertambahan tinggi tanaman kacang tanah. Demikian juga pada penelitian Sumarwoto, (2004) bahwa pemberian $\mathrm{Ca}$ atau kapur sebanyak 20 ton/ha sangat mempengaruhi pertumbuhan tanaman dari pada tanpa pengapuran.

Bahan organik selain dapat meningkatkan kesuburan tanah juga mempunyai peran penting dalam memperbaiki sifat fisik tanah. Bahan organik dapat meningkatkan agregasi tanah, memperbaiki aerasi dan perkolasi, serta membuat struktur tanah menjadi lebih remah dan mudah diolah (Prasetyo \& Suriadikarta, 2006).

Tandan Kosong Kelapa Sawit (TKKS) merupakan limbah yang dihasilkan sebanyak 23\% dari tandan buah segar (TBS). TKKS merupakan bahan organik yang mengandung unsur hara $\mathrm{N}, \mathrm{P}, \mathrm{K}$ dan $\mathrm{Mg}$. Salah satu pemanfaatan TKKS adalah pemanfaatan TKKS sebagai kompos (Darnoko \& Sembiring, 2005).

Sludge adalah benda padat yang tenggelam di dasar bak pengendapan dalam sarana pengelolaan limbah dan harus dibuang atau dikelola untuk mengurangi pencemaran lingkungan. Sludge dihasilkan dari pengolahan minyak sawit yang mengandung unsure hara Nitrogen, Posfor dan kalium, magnesium dan kalsium yang cukup tinggi sehingga dapat digunakan sebagai pupuk (Siregar, 2007).

Tujuan penelitian ini untuk mengetahui efektifitas pemberian KapTan dan komposisi Berbagai media tanam bahan organik padat pada pertumbuhan 
bibit kelapa sawit (Elaeis guineensis Jacq) di pembibitan awal.

\section{METODE}

\section{Waktu dan Tempat Penelitian}

Penelitian ini dilaksanakan pada Agustus sampai November 2014 di kebun masyarakat, Tanjung Morawa

\section{Bahan dan Alat}

Tanah yang digunakan dalam penelitian ini adalah media tanah topsoil ultisol, baby polybag $10 \mathrm{~kg}$ ukuran lebar $25 \mathrm{~cm}$ ketebalan $0,15 \mathrm{~mm}$, benih tanaman kelapa sawit DxP keluaran RISPA Medan, pupuk kalsium $(\mathrm{CaO})$ yang diambil dari kapur tani, bahan organik padat sludge limbah padat kelapa sawit, kompos tandan kosong kelapa sawit, kompos kandang sapi. insektisida decis, herbisida roundup, fungisida dithane M-45. Alat-alat yang digunakan antara lain cangkul, gembor, label nama, alat tulis, plastik, ember, meteran, kalkulator, pompa air.

\section{Medel Rancangan}

Penelitian dilakukan dengan menggunakan rancangan acak kelompok (RAK) faktorial dengan dua perlakuan yaitu faktor pertama: pemberian pupuk kalsium (KapTan) dengan 3 taraf : $\mathrm{P}_{0}=$ tanpa pupuk kalsium, $\mathrm{P}_{1}=$ pupuk kalsium 2 ton/ha (10 g/polybag), $\mathrm{P}_{2}=$ pupuk kalsium 4 ton/ha $(20 \mathrm{~g} /$ polybag). Faktor kedua: media tanam dengan 4 taraf $M_{0}=$ tanpa bahan organik (topsoil), $\mathrm{M}_{1}=$ topsoil + kompos kandang sapi $(1: 1), \mathbf{M}_{2}=$ topsoil + sludge padat $(1: 1), \mathbf{M}_{3}=$ topsoil + kompos TKKS (1:1).

\section{Persiapan Media}

Media tanam yang digunakan adalah tanah topsoil kemudian diayak dan dibersihkan dari sisa-sisa tumbuhan dan kotoran lainnya. Setelah itu dimasukkan kedalam baby polibag $10 \mathrm{~kg}$ ukuran lebar $25 \mathrm{~cm}$ dan tebal $0,15 \mathrm{~mm}$.

\section{Persiapan Lahan}

Lahan areal penelitian dibersihkan dari gulma dan tanaman lain yang tumbuh diatasnya kemudian lahan diolah dengan traktor dan dicangkul sampai siap tanam, kemudian dibuat petak-petak percobaan berukuran $90 \mathrm{~cm}$ x $60 \mathrm{~cm}$. Lahan penelitian diberikan atau dibuat naungan sesuai dengan standard pembuatan nanungan dipembibitan. Kemudian diatur sedemikian rupa sesuai dengan perlakuan. Setiap percobaan dalam satu plot dibatasi oleh parit drainase selebar $50 \mathrm{~cm}$, sedangkan jarak antar ulangan selebar $100 \mathrm{~cm}$.

\section{Penanaman Kecambah ke Polibag}

Kecambah yang telah tumbuh diarea perkecambahan kemudian ditanam pada lubang yang telah disiapkan dipolibag yang telah terisi media tanah topsoil dari lahan.

\section{Pemberian Pupuk Kalsium}

Pupuk yang diberikan adalah pupuk kapur tani (KapTan) $\mathrm{CaO}$ yakni kalsium yang sesuai dengan perlakuan yakni $\mathrm{P} 0=$ tanpa pupuk kalsium, $\mathrm{P} 1=$ pupuk kalsium 2 ton/ha (10 g/polybag), P2= pupuk kalsium 4 ton/ha (20 g/polybag), pemberian pupuk kalsium diberikan 2 kali, satu kali seminggu sebelum tanam dan sebulan sesudah tanam.

\section{HASIL DAN PEMBAHASAN \\ Tinggi Tanaman (cm)}

Hasil sidik ragam menunjukkan bahwa perlakuan pupuk kalsium berpengaruh tidak nyata terhadap tinggi tanaman. Perlakuan media tanam berpengaruh nyata terhadap tinggi tanaman. Interaksi keduanya berpengaruh tidak nyata terhadap tinggi tanaman (Tabel 1).

Tabel 1. Hasil uji beda rataan pemberian pupuk kalsium dan komposisi berbagai media tanam terhadap tinggi tanaman kelapa sawit umur 9 MST.

\begin{tabular}{ccccc}
\hline Perlakuan & $\mathrm{P}_{0}$ & $\mathrm{P}_{1}$ & $\mathrm{P}_{2}$ & Rataan \\
\hline $\mathrm{M}_{0}$ & 15,27 & 16,57 & 14,40 & $15,41 \mathrm{a}$ \\
$\mathrm{M}_{1}$ & 17,43 & 18,30 & 17,30 & $17,68 \mathrm{~b}$ \\
$\mathrm{M}_{2}$ & 16,20 & 16,57 & 17,63 & $16,80 \mathrm{a}$ \\
$\mathrm{M}_{3}$ & 16,00 & 15,67 & 17,13 & $16,27 \mathrm{a}$ \\
\hline Rataan & $16,23 \mathrm{a}$ & $16,78 \mathrm{a}$ & $16,62 \mathrm{a}$ & \\
\hline
\end{tabular}

Keterangan: angka-angka yang diikuti huruf yang sama pada baris atau kolom yang sama menujukkan tidak berbeda nyata pada $\mathrm{BNJ}$ taraf $5 \%$. KK=9,72\%.

Hasil uji beda rataan Tabel 1 terlihat bahwa perlakuan pemberian pupuk kalsium berpengaruh tidak nyata terhadap tinggi tanaman dimana perlakuan tertinggi $\mathrm{P}_{1}(16,78 \mathrm{~cm})$ diikuti dengan $\mathrm{P}_{2}(16,62 \mathrm{~cm})$ dan $\mathrm{P}_{0}(16,23$ $\mathrm{cm})$. Perlakuan media tanam berpengaruh nyata terhadap tinggi tanaman dimana $\mathrm{M}_{1}(17,68 \mathrm{~cm})$ berbeda nyata dengan $\mathrm{M}_{2}(16,80 \mathrm{~cm}), \mathrm{M}_{3}(16,27 \mathrm{~cm})$ dan $\mathrm{M}_{0}(15,41 \mathrm{~cm})$. Interaksi kedua perlakuan berpengaruh tidak nyata terhadap tinggi tanaman dengan perlakuan tertinggi $\mathrm{P}_{1} \mathbf{M}_{1}$ $(18,30 \mathrm{~cm})$.

\section{Luas Daun $\left(\mathrm{cm}^{2}\right)$}

Hasil sidik ragam menunjukkan bahwa perlakuan pupuk kalsium berpengaruh nyata terhadap luas daun. Perlakuan media tanam berpengaruh nyata terhadap luas daun. Interaksi keduanya berpengaruh tidak nyata terhadap luas daun (Tabel 2).

Tabel 2. Hasil uji beda rataan pemberian pupuk kalsium dan komposisi berbagai media tanam terhadap luas daun $\left(\mathrm{cm}^{2}\right)$ umur 9 MST.

\begin{tabular}{ccccc}
\hline Perlakuan & $\mathrm{P}_{0}$ & $\mathrm{P}_{1}$ & $\mathrm{P}_{2}$ & Rataan \\
\hline $\mathrm{M}_{0}$ & 58,75 & 55,25 & 64,57 & $59,52 \mathrm{a}$ \\
$\mathrm{M}_{1}$ & 63,39 & 67,78 & 63,39 & $64,85 \mathrm{ab}$ \\
$\mathrm{M}_{2}$ & 55,85 & 50,09 & 64,22 & $56,72 \mathrm{a}$ \\
$\mathrm{M}_{3}$ & 57,69 & 57,69 & 62,57 & $59,32 \mathrm{a}$ \\
\hline Rataan & $58,92 \mathrm{a}$ & $57,70 \mathrm{a}$ & $63,69 \mathrm{~b}$ & \\
\hline
\end{tabular}

Keterangan: angka-angka yang diikuti huruf yang sama pada baris atau kolom yang sama menujukkan tidak berbeda nyata pada $\mathrm{BNJ}$ taraf $5 \%$. KK=9,72\%.

Hasil uji beda rataan Tabel 2 terlihat bahwa perlakuan pemberian pupuk kalsium berpengaruh nyata terhadap luas daun dimana $\mathrm{P}_{2}\left(16,78 \mathrm{~cm}^{2}\right)$ berbeda nyata dengan $\mathrm{P}_{0}\left(58,92 \mathrm{~cm}^{2}\right)$ dan $\mathrm{P}_{1}\left(57,70 \mathrm{~cm}^{2}\right)$. Perlakuan media tanam berpengaruh nyata terhadap luas daun dimana $M_{1}\left(64,85 \mathrm{~cm}^{2}\right)$ tidak berbeda nyata dengan $M_{0}$ 
$\left(59,52 \mathrm{~cm}^{2}\right), \mathrm{M}_{3}\left(59,32 \mathrm{~cm}^{2}\right)$ dan $\mathrm{M}_{2}\left(56,72 \mathrm{~cm}^{2}\right)$. Interaksi kedua perlakuan berpengaruh tidak nyata terhadap luas daun dengan perlakuan tertinggi $\mathrm{P}_{1} \mathrm{M}_{1}$ $\left(67,78 \mathrm{~cm}^{2}\right)$.

\section{Volume Akar Tanaman (mm)}

Hasil sidik ragam menunjukkan bahwa perlakuan pupuk kalsium dan interaksinya berpengaruh tidak nyata terhadap volume akar, namun media tanam berpengaruh nyata terhadap volume akar (Tabel 3).

Tabel 3. Hasil uji beda rataan pemberian pupuk kalsium dan komposisi berbagai media tanam terhadap volume akar tanaman (mm) umur 9 MST.

\begin{tabular}{ccccc}
\hline Perlakuan & $\mathrm{P}_{0}$ & $\mathrm{P}_{1}$ & $\mathrm{P}_{2}$ & Rataan \\
\hline $\mathrm{M}_{0}$ & 0,65 & 0,67 & 0,75 & $0,69 \mathrm{a}$ \\
$\mathrm{M}_{1}$ & 0,73 & 0,90 & 0,83 & $0,82 \mathrm{~b}$ \\
$\mathrm{M}_{2}$ & 0,65 & 0,72 & 0,65 & $0,67 \mathrm{a}$ \\
$\mathrm{M}_{3}$ & 0,72 & 0,60 & 0,68 & $0,67 \mathrm{a}$ \\
\hline Rataan & 0,69 & 0,72 & 0,73 &
\end{tabular}

Keterangan: angka-angka yang diikuti huruf yang sama pada baris atau kolom yang sama menujukkan tidak berbeda nyata pada $\mathrm{BNJ}$ taraf $5 \%$. $\mathrm{KK}=6,34 \%$.

Hasil uji beda rataan Tabel 3 terlihat bahwa perlakuan pemberian pupuk kalsium berpengaruh tidak nyata terhadap volume akar dimana perlakuan tertinggi $\mathrm{P}_{2}(0,73 \mathrm{~mm})$ diikuti $\mathrm{P}_{1}(0,72 \mathrm{~mm})$ dan $\mathrm{P}_{0}(0,69 \mathrm{~mm})$. Perlakuan media tanam berpengaruh nyata terhadap volume akar dimana $\mathrm{M}_{1}(0,82 \mathrm{~mm})$ berbeda nyata dengan $M_{0}(0,69 \mathrm{~mm}), M_{2}(0,67 \mathrm{~mm})$ dan $M_{3}(0,67 \mathrm{~mm})$. Interaksi kedua perlakuan berpengaruh tidak nyata terhadap volume akar tertinggi $\mathrm{P}_{1} \mathrm{M}_{1}(0,90 \mathrm{~mm})$.

\section{Berat Basah Tanaman (g)}

Hasil sidik ragam menunjukkan bahwa perlakuan pupuk kalsium dan interaksinya berpengaruh tidak nyata terhadap bobot basah tanaman. Perlakuan media tanam berpengaruh nyata terhadap bobot basah tanaman (Tabel 4).

Tabel 4. Hasil uji beda rataan pemberian pupuk kalsium dan komposisi berbagai media tanam terhadap berat basah tanaman umur 9 MST.

\begin{tabular}{ccccc}
\hline Perlakuan & $\mathrm{P}_{0}$ & $\mathrm{P}_{1}$ & $\mathrm{P}_{2}$ & Rataan \\
\hline $\mathrm{M}_{0}$ & 12,18 & 21,08 & 13,30 & $15,52 \mathrm{a}$ \\
$\mathrm{M}_{1}$ & 23,12 & 27,14 & 21,93 & $24,06 \mathrm{~b}$ \\
$\mathrm{M}_{2}$ & 21,37 & 16,01 & 13,76 & $17,05 \mathrm{a}$ \\
$\mathrm{M}_{3}$ & 17,60 & 17,60 & 17,65 & $17,61 \mathrm{a}$ \\
\hline Rataan & 18,57 & 20,46 & 16,66 & \\
\hline
\end{tabular}

Keterangan: angka-angka yang diikuti huruf yang sama pada baris atau kolom yang sama menujukkan tidak berbeda nyata pada $\mathrm{BNJ}$ taraf $5 \%$. $\mathrm{KK}=6,34 \%$.

Hasil uji beda rataan Tabel 4 terlihat bahwa perlakuan pemberian pupuk kalsium berpengaruh tidak nyata terhadap bobot basah tanaman dimana perlakuan tertinggi $\mathrm{P}_{1}(20,46 \mathrm{~g})$ diikuti $\mathrm{P}_{0}(18,57 \mathrm{~g})$ dan $\mathrm{P}_{2}(16,66 \mathrm{~g})$. Perlakuan media tanam berpengaruh nyata terhadap bobot basah tanaman dimana $\mathrm{M}_{1}(24,06 \mathrm{~g})$ berbeda nyata dengan $\mathrm{M}_{3}(17,61 \mathrm{~g}), \mathrm{M}_{2}(17,05 \mathrm{~g})$ dan $\mathrm{M}_{0}(15,52 \mathrm{~g})$. Interaksi kedua perlakuan berpengaruh tidak nyata terhadap bobot basah tanaman dengan perlakuan tertinggi $\mathrm{P}_{1} \mathrm{M}_{1}(27,14 \mathrm{~g})$

\section{Berat Kering Tanaman (g)}

Hasil sidik ragam menunjukkan bahwa perlakuan pupuk kalsium dan interaksinya berpengaruh tidak nyata terhadap bobot kering tanaman. Perlakuan media tanam berpengaruh nyata terhadap bobot kering tanaman kelapa sawit (Tabel 5)

Tabel 5. Hasil uji beda rataan pemberian pupuk kalsium dan komposisi berbagai media tanam terhadap berat kering tanaman umur 9 MST.

\begin{tabular}{ccccc}
\hline Perlakuan & $\mathrm{P}_{0}$ & $\mathrm{P}_{1}$ & $\mathrm{P}_{2}$ & Rataan \\
\hline $\mathrm{M}_{0}$ & 3,08 & 5,17 & 3,33 & $3,86 \mathrm{a}$ \\
$\mathrm{M}_{1}$ & 6,02 & 7,04 & 5,65 & $6,24 \mathrm{~b}$ \\
$\mathrm{M}_{2}$ & 5,26 & 4,21 & 3,61 & $4,36 \mathrm{a}$ \\
$\mathrm{M}_{3}$ & 4,40 & 4,63 & 4,41 & $4,48 \mathrm{a}$ \\
\hline Rataan & 4,69 & 5,26 & 4,25 & 4,74 \\
\hline Keterangan: angka-angka yang diikuti huruf yang sama pada \\
\multicolumn{5}{c}{ baris atau kolom yang sama menujukkan tidak } \\
\multicolumn{5}{c}{ berbeda nyata pada BNJ taraf 5\%. KK=6,34\%. }
\end{tabular}

Hasil uji beda rataan Tabel 5 terlihat bahwa perlakuan pemberian pupuk kalsium berpengaruh tidak nyata terhadap bobot kering tanaman dimana perlakuan tertinggi $\mathrm{P}_{1}(5,26 \mathrm{~g})$ diikuti $\mathrm{P}_{0}(4,69 \mathrm{~g})$ dan $\mathrm{P}_{2}(4,25 \mathrm{~g})$. Perlakuan media tanam berpengaruh nyata terhadap bobot kering tanaman dimana $\mathrm{M}_{1}(6,24 \mathrm{~g})$ berbeda nyata dengan $\mathrm{M}_{3}(4,48 \mathrm{~g}), \mathrm{M}_{2}$ (4,36 g) dan $\mathrm{M}_{0}$ (3,86 g). Interaksi kedua perlakuan berpengaruh tidak nyata terhadap bobot kering tanaman dengan perlakuan tertinggi $\mathrm{P}_{1} \mathrm{M}_{1}(7,04 \mathrm{~g})$.

\section{Berat Basah Akar Tanaman (g)}

Hasil sidik ragam menunjukkan bahwa perlakuan pupuk kalsium dan interaksinya berpengaruh tidak nyata terhadap bobot basah akar tanaman. Perlakuan media tanam berpengaruh nyata terhadap bobot basah akar tanaman (Tabel 6).

Tabel 6. Hasil uji beda rataan pemberian pupuk kalsium dan komposisi berbagai media tanam terhadap berat basah akar tanaman umur 9 MST

\begin{tabular}{ccccc}
\hline Perlakuan & $\mathrm{P}_{0}$ & $\mathrm{P}_{1}$ & $\mathrm{P}_{2}$ & Rataan \\
\hline $\mathrm{M}_{0}$ & 3,08 & 5,25 & 3,33 & $3,89 \mathrm{a}$ \\
$\mathrm{M}_{1}$ & 5,84 & 6,79 & 5,48 & $6,04 \mathrm{~b}$ \\
$\mathrm{M}_{2}$ & 5,34 & 4,00 & 3,44 & $4,26 \mathrm{a}$ \\
$\mathrm{M}_{3}$ & 4,40 & 4,40 & 4,41 & $4,40 \mathrm{a}$ \\
\hline Rataan & 4,67 & 5,11 & 4,17 &
\end{tabular}

Keterangan: angka-angka yang diikuti huruf yang sama pada baris atau kolom yang sama menujukkan tidak berbeda nyata pada $\mathrm{BNJ}$ taraf $5 \%$.

Hasil uji beda rataan Tabel 6 terlihat bahwa perlakuan pemberian pupuk kalsium berpengaruh tidak nyata terhadap bobot basah akar tanaman dimana perlakuan tertinggi $\mathrm{P}_{1}(5,11 \mathrm{~g})$ diikuti $\mathrm{P}_{0}(4,67 \mathrm{~g})$ dan $\mathrm{P}_{2}$ $(4,17 \mathrm{~g})$. Perlakuan media tanam berpengaruh nyata terhadap bobot basah akar tanaman dimana $\mathrm{M}_{1}(6,04 \mathrm{~g})$ berbeda nyata dengan $\mathbf{M}_{3}(4,40 \mathrm{~g}), \mathbf{M}_{2}(4,26 \mathrm{~g})$ dan $\mathrm{M}_{0}$ $(3,86 \mathrm{~g})$. Interaksi kedua perlakuan berpengaruh tidak nyata terhadap bobot kering tanaman dengan perlakuan tertinggi $\mathrm{P}_{1} \mathrm{M}_{1}(6,79 \mathrm{~g})$.

\section{Berat Kering Akar Tanaman (g)}

Hasil sidik ragam menunjukkan bahwa perlakuan pupuk kalsium dan interaksinya berpengaruh tidak nyata 
terhadap bobot kering akar tanaman. Perlakuan media tanam berpengaruh nyata terhadap bobot kering akar tanaman (Tabel 7).

Tabel 7. Hasil uji beda rataan pemberian pupuk kalsium dan komposisi berbagai media tanam terhadap berat kering akar tanaman umur 9 MST.

\begin{tabular}{ccccc}
\hline Perlakuan & $\mathrm{P}_{0}$ & $\mathrm{P}_{1}$ & $\mathrm{P}_{2}$ & Rataan \\
\hline $\mathrm{M}_{0}$ & 2,31 & 3,93 & 2,49 & $2,91 \mathrm{a}$ \\
$\mathrm{M}_{1}$ & 4,38 & 5,09 & 4,11 & $4,53 \mathrm{~b}$ \\
$\mathrm{M}_{2}$ & 4,00 & 3,00 & 2,58 & $3,19 \mathrm{a}$ \\
$\mathrm{M}_{3}$ & 3,30 & 3,30 & 3,02 & $3,21 \mathrm{a}$ \\
\hline Rataan & 3,50 & 3,83 & 3,05 & 3,46
\end{tabular}

Keterangan: angka-angka yang diikuti huruf yang sama pada baris atau kolom yang sama menujukkan tidak berbeda nyata pada BNJ taraf 5\%.

Hasil uji beda rataan Tabel 7 terlihat bahwa perlakuan pemberian pupuk kalsium berpengaruh tidak nyata terhadap bobot kering akar tanaman dimana perlakuan tertinggi $\mathrm{P}_{1}(3,83 \mathrm{~g})$ diikuti $\mathrm{P}_{0}(3,50 \mathrm{~g})$ dan $\mathrm{P}_{2}$ $(3,05 \mathrm{~g})$. Perlakuan media tanam berpengaruh nyata terhadap bobot basah akar tanaman dimana $\mathbf{M}_{1}(4,53 \mathrm{~g})$ berbeda nyata dengan $\mathbf{M}_{3}(3,21 \mathrm{~g}), \mathbf{M}_{2}(3,19 \mathrm{~g})$ dan $\mathbf{M}_{0}$ $(2,91 \mathrm{~g})$. Interaksi kedua perlakuan berpengaruh tidak nyata terhadap bobot kering tanaman dengan perlakuan tertinggi $\mathrm{P}_{1} \mathrm{M}_{1}(5,09 \mathrm{~g})$.

\section{Pengaruh pupuk kalsium terhadap pertumbuhan bibit tanaman kelapa sawit di pembibitan awal}

Dari hasil penelitian dapat dilihat bahwa pemberian perlakuan dengan pemberian pupuk kalsium (KapTan) dengan taraf perlakuan yang berbeda memberikan hasil yang tidak nyata pada semua parameter pengamatan yakni tinggi tanaman, volume akar, bobot basah tanaman, bobot kering tanaman, bobot basah tanaman, bobot kering akar tanaman. Hal ini disebabkan kerena unsur hara kalsium (Ca) (Kaptan) bersifat slow release dengan volume pelepasan mendekati kapasitas akar tanaman dalam menyerap unsur hara (Wigena et al.,2006). Dengan demikian, respon tanaman terhadap Ca relatif lambat.

$$
\text { Pemberian pupuk Kalsium (Kaptan) }
$$
memberikan hasil yang nyata pada luas daun tanaman kelapa sawit umur 9 MST. Menurut Tuteja \& Mahajan, (2007), kalsium berperan sebagai nutrisi tanaman yang diperlukan untuk pertumbuhan dan perkembangan khususnya akar dan tunas. Bagi tanaman, kalsium (Ca) bertugas untuk merangsang pembentukan bulu-bulu akar, mengeraskan batang tanaman, dan merangsang pembentukkan biji. Kalsium yang terdapat pada batang dan daun ini berkhasiat untuk menetralisasikan senyawa atau suasana yang tidak menguntungkan pada tanah.

$$
\text { Pemberian KapTan (kalsium) dapat }
$$

meningkatkan $\mathrm{pH}$ tanah dan proses kimia dalam tanah.Efek kimia yakni terjadi perubahan $\mathrm{pH}$ tanah yang mengakibatkan terjadi perubahan konsentrasi ion $\mathrm{pH}$, kelarutan $\mathrm{Fe}, \mathrm{Al}, \mathrm{Mn}$ sehingga kondisi $\mathrm{pH}$ tanah meningkat mendekati netral. Efek biologisnya berupa peningkatan kegiatan bahan organik dan nitrogen dalam tanah masam karena kapur menstimulir organisme tanah (Buckman \& Brady, 1982).

\section{Pengaruh komposisi berbagai media tanam terhadap pertumbuhan bibit tanaman kelapa sawit di pembibitan awal}

Dari hasil penelitian dapat dilihat bahwa pemberian perlakuan dengan komposisi berbagai media tanam memberikan pengaruh yang nyata pada pada semua parameter pengamatan yakni tinggi tanaman, luas daun, volume akar, bobot basah tanaman, bobot kering tanaman, bobot basah tanaman, bobot kering akar tanaman.Hal ini disebabkan karena komposisi berbagai media tanam yang merupakan bahan otrganik mempengaruhi pertumbuhan tanaman bibit kelapa sawit tersebut.

Bibit kelapa sawit membutuhkan unsur hara $\mathrm{N}$ yang cukup tinggi untuk membentuk sel dan jaringan baru pada masa pertumbuhan vegetatif, khususnya tinggi bibit kelapa sawit. Notohadiprawiro et al., (2006) menyatakan bahwa nitrogen sangat dibutuhkan oleh tanaman pada fase pertumbuhan vegetatif, khususnya pertumbuhan batang yang memacu pertumbuhan tinggi tanaman. Menurut Sarief (2003) bahwa pertumbuhan tinggi tanaman dipengaruhi oleh ketersediaan nitrogen yang cukup yang berperan dalam proses pembelahan sel. Nitrogen mempunyai peran utama untuk merangsang pertumbuhan secara keseluruhan dan khususnya pertumbuhan batang yang dapat memacu pertumbuhan tinggi tanaman.

Sesuai dengan pendapat Sutedjo \& Kartasapoetra, (2002) bahwa untuk pertumbuhan vegetatif tanaman sangat diperlukan unsur hara seperti $\mathrm{N}, \mathrm{K}$ dan unsur lainnnya dalam jumlah yang cukup dan seimbang. Hal ini bisa didapatkan dari pupuk organik seperti kompos, karena memiliki kandungan hara yang lengkap meskipun persentasenya kecil. Kompos juga mengandung senyawasenyawa lain yang sangat bermanfaat bagi tanaman. Menurut Mulyani, (2002) apabila porositas tanah baik, maka keseimbangan turgor tanaman menjadi baik hal ini diperlukan untuk proses fotosintesis. Hasil fotosintesis akan banyak dimanfaatkan oleh tanaman untuk pertumbuhannya.

Menurut Anjarsari et al., (2007) bobot kering tanaman merupakan salah satu indikator pertumbuhan tanaman. Nilai bobot kering tanaman yang tinggi menunjukkan terjadinya peningkatan proses fotosintesis karena unsur hara yang diperlukan cukup tersedia. Hal tersebut berhubungan dengan hasil fotosintat yang ditranslokasikan ke seluruh organ tanaman untuk pertumbuhan tanaman, sehingga memberikan pengaruh yang nyata pada biomassa tanaman.Hal ini juga diperkuat oleh Leiwakabessy, (1997) mengatakan bahwa pertumbuhan dan perkembangan tanaman sangat dipengaruhi oleh unsur hara yang tersedia pertumbuhan akan maksimum jika unsur hara yang tersedia dalam keadaa optimum dan seimbang. Gardner et al., (1991) dalam Valentinus et al., (2012) menyatakan bahwa unsur hara yang tersedia pada konsentrasi tertentu dapat meningkatkan pembentukan protein, karbohidrat dan lemak yang dibentuk tanaman dalam proses fotosintesis dan asimilasi digunakan oleh tanaman untuk pembentukan dan perkembangan sel baru.

Menurut Syarif, (2003) bahwa untuk tanaman tahunan, penambahan jumlah daun dan luas daun 
membutuhkan unsur hara yang seimbang dan berlanjut dalam waktu yang cukup lama. Pada tanaman tahunan atau tanaman berumur panjang lamanya daun untuk membuka sempurna setelah keluar dari tunasnya membutuhkan waktu kira-kira satu bulan. Jumlah daun yang terbentuk dipengaruhi oleh tinggi tanaman, dimana semakin tinggi tanaman maka jumlah yang muncul akan semakin bertambah karena adanya tunas-tunas baru yang akhirnya tunas ini berkembang menjadi daun. Hal ini sesuai dengan pendapat Setyamidjaja, (1986) bahwa semakin tinggi suatu tanaman maka jumlah daun yang muncul semakin bertambah pula sehingga dapat meningkatkan proses fotosintesis yang dapat menyimpan karbohidrat serta gula didalam daun yang dapat dimanfaatkan oleh daun untuk proses pembelahan dan perpanjangan sel. Menurut Sarief, (2003) bahwa penambahan bahan organik mempunyai nilai tertentu yakni membentuk agregat tanah yang baik dari partikelpartikel tanah Menurut Salisbury \& Ross, (1995) bahwa penyerapan unsur hara terutama unsur hara nitrogen berpengaruh terhadap pembentukan luas daun.

Penggunaan media tanam dengan campuran topsoil dan pupuk kompos kandang sapi pada penelitian ini memberikan hasil yang terbaik dengan perlakuan media tanam - media tanam lainnya. Hal ini karena pupuk kandang sapi yang telah dikomposkan dapat memperbaiki agregat tanah dan daya pegang air serta porositas tanah sehingga dapat meningkatkan pertumbuhan kelapa sawit. Hal ini dapat dilihat pada penelitian Sriyanto et al., (2015) menyatakan bahwa pupuk kandang sapi merupakan pupuk organik yang baik sebagai pupuk dasar karena dapat memperbaiki kesuburan tanah menjaga struktur tanah tetap gembur dan meningkatkan daya serap dan daya pegang tanah terhadap air sehingga ketersediaan air yang dibutuhkan tanaman memadai, selanjutnya dalam penelitian ini menjelaskan juga bahwa pemberian pupuk kandang sapi dapat meningkatkan ketersediaan dan serapan unsur $\mathrm{N}$ yang sangat dibutuhkan dalam pertumbuhan vegetatif tanaman. Seperti dikemukakan oleh Sarif, (2003) dalam Sriyanto et al., (2015) bahwa unsur nitrogen (N) sangat diperlukan tanaman untuk merangsang pertumbuhan vegetatif tanaman seperti batang, akar, daun dan cabang. Dengan tersedianya unsur $\mathrm{N}$ dapat memacu pertumbuhan tinggi tanaman.

Penggunaan kompos TKKS sebagai campuran media tanam berperan dalam hal ketersediaan air. Bahan organik adalah bahan pemantap agregat tanah yang sangat baik dan merupakan sumber dari unsur hara tumbuhan. Bahan organik merupakan perekat butiran lepas, mampu meningkatkan jumlah air yang dapat ditahan di dalam tanah dan jumlah air yang tersedia pada tanaman. Bahan organik yang diberikan (dalam hal ini kompos TKKS) mampu menyerap air 2-4 kali lipat bobotnya. Karena kandungan air tersebut maka kompos TKKS dapat menjadi penyangga bagi ketersediaan air. Tanah yang mengandung banyak bahan organik dapat menyimpan lebih banyak air sehingga kelembaban tanah akan terjaga sehingga pertumbuhan bibit menjadi lebih baik dibandingkan pada media campuran dibandingkan dengan media tunggal (Nasution et al., 2014).
Interaksi pupuk kalsium dan komposisi berbagai media tanam terhadap pertumbuhan bibit kelapa sawit di pembibitan awal

Dari hasil penelitian dapat dilihat bahwa Interaksi pupuk kalsium (KapTan) dan komposisi berbagai media tanam terhadap pertumbuhan vegetative bibit tanaman kelapa sawit (Elaeis guineensis Jacq) di pembibitan awal tidak memberikan pengaruh yang nyata pada semua paremeter pengamatan Hal ini disebabkan karena perlakuan yang diberikan belum mampu mempengaruhi pola aktivitas fisiologi tanaman secara interval, walaupun diantara perlakuan yang diuji telah mampu mendukung pertumbuhan tanaman secara fisiologi.

Adapun hal lain yang menyebabkan tidak adanya pengaruh yang nyata terhadap seluruh parameter yang diamati diduga interaksi kedua perlakuan kurang saling mendukung satu sama lainnya, sehingga efeknya akar tanaman tidak respon dan ini sesuai dengan pendapat Hakim et al., (1986) menyatakan bahwa pertumbuhan tanaman yang baik dapat tercapai bila faktor yang mempengaruhi pertumbuhan berimbang dan menguntungkan.

Dalam hal lain faktor luar dari tanaman itu sendiri kurang mendukung aktivitas dari kedua perlakuan, sebab kombinasi dari kedua perlakuan tertentu tidak selamanya akan memberikan pengaruh yang baik pada tanaman. Ada kalanya kombinasi tersebut akan mendorong pertumbuhan, menghambat pertumbuhan atau sama sekali tidak memberikan respon terhadap pertumbuhan dan perkembangan tanaman.

\section{KESIMPULAN}

Pemberian pupuk KapTan $(\mathrm{CaO}=$ Kalsium $)$ belum dapat memberikan pengaruh yang nyata pada tinggi tanaman, luas daun, volume akar, bobot basah tanaman, bobot kering tanaman, bobot basahakar tanaman, bobot kering akar tanaman kelapa sawit di pembibitan awal Pemberian ragam media tanam dapat memberikan pengaruh yang nyata pada tinggi tanaman, luas daun, volume akar, bobot basah tanaman, bobot kering tanaman, bobot basah tanaman, bobot kering akar tanaman kelapa sawit di pembibitan awal. Interaksi pupuk Kaptan (kalsium) dan ragam media tanam terhadap pertumbuhan vegetative bibit tanaman kelapa sawit belum dapat memberikan pengaruh yang nyata pada tinggi tanaman, luas daun, volume akar, bobot basah tanaman, bobot kering tanaman, bobot basahakar tanaman, bobot kering akar tanaman kelapa sawit di pembibitan awal. Media tanam yang terbaik adalah Media tanam top soil dengan kompos kandang sapi dan Media tanam topsoil dengan kompos TKKS serta perlakuan yang terbaik pada penelitian ini adalah pada perlakuan $\mathrm{P}_{1} \mathrm{M}_{1}$.

\section{DAFTAR PUSTAKA}

Anjarsari, I. R. D. 2007. Pengaruh Kombinasi Pupuk P dan Kompos Terhadap Pertumbuhan Tanaman Teh (Camellia sinensis (L.) o. kuntze) Belum Menghasilkan Klon Gambung 7. Dikutip dari http://pustaka.unpad.ac.id. Diakses pada tanggal 
15 Desember 2015.

Buckman, H. O., dan Brady, N.C. 1982. Ilmu Tanah. Terjemahan. Bharata Karya Aksara. Jakarta.

Darnoko, D., dan Sembiring, T. 2005. Sinergi antara perkebunan kelapa sawit dan pertanian tanaman pangan melalui aplikasi kompos TKKS untuk tanaman padi. Pertemuam Teknis Kelapa Sawit 2005: Peningkatan Produktifitas Kelapa Sawit Melalui Pemupukan dan Pemanfaatan Limbah PKS. Medan 19-20 April. Hal. 1-58.

Nasution, H. H., Hanum, C., dan Lahay, R. R. 2014. Pertumbuhan Bibit Kelapa Sawit (Elaeis guineensis Jacq.) Pada Berbagai Perbandingan Media Tanam Sludge dan tandan Kosong Kelapa Sawit (TKKS) di Pre-Nursery. Jurnal Online Agroekoteknologi, 2(4), 1419-1425.

Prasetyo, B. H., dan Suriadikarta, D. A. 2006. Karakteristik, Potensi dan Teknologi Pengelolaan Tanah Ultisol untuk Pengembangan Pertanian Lahan Keing di Indonesia. Jurnal Litbang Pertanian, 25(2), 39-46.

Sarief, F. S. 2003. Kesuburan dan Pemupukan Pertanian. Pustaka Buana. Bandung.

Sriyanto D., Astuti, P., dan Sujalu, A. P. 2015. Pengaruh Dosis Pupuk Kandang sapi dan hasil Tanaman Terung Ungu dan terung Hijau (Solanum melangona L.). Agrifor: Jurnal Ilmu Pertanian dan Kehutanan, 14(1), 39-44. https://doi.org/10.31293/af.v14i1.1099.

Sumarwoto. 2004. Pengaruh Pemberian Kapur dan Ukuran Bulbi Terhadap Pertumbuhan Iles-Iles Pada Tanah Ber-Al Tinggi. Ilmu Pertanian, 11(2), 45-53. https://doi.org/10.22146/ipas.59951.

Sutejo. M. M, dan Kartasapoetra. 2002. Pupuk dan Cara Pemupukan. Rineka Cipta. Jakarta.

Tuteja, N., \& Mahajan, S. 2007. Further characterization of calcineurin B-like protein and its interacting partner CBL-interacting protein kinase from Pisum sativum. Plant Signaling \& Behavior, 2(5), 358361. https://doi.org/10.4161/psb.2.5.4178.

Wigena, I. G. P., Purnomo, J., Tuherkih, E., \& Saleh, A. 2006. Pengaruh pupuk "slow release" majemuk padat terhadap pertumbuhan dan produksi kelapa sawit muda pada Xanthic Hapludox di Merangin. Jambi. Jurnal Tanah Iklim, 24, 10-19. http://dx.doi.org/10.21082/jti.v0n24.2006.\%25p. 